\title{
KOMPETENSI TUTOR KEAKSARAAN FUNGSIONAL DALAM PENGELOLAAN PEMBELAJARAN DI KECAMATAN WARA UTARA KOTA PALOPO PROVINSI SULAWESI SELATAN
}

\begin{abstract}
Akram*
Abstract

In nonformal education, tutors are to assist learners to learn as well as to motivate them. To make these tutors be able to improve their competencies, they should get appropriate/relevant trainings. This article reports a researchs on tutors competency in conducting instruction for functional literacy program in Wara Utara . Research findings show tutor are still lack of competencies in assisting and motivating learners in an instructional situation. It's recommended that they should be trained on learning motivation.
\end{abstract}

Key words: tutors competency, functional literacy, instructional management

\section{PENDAHULUAN}

\section{Latar Belakang}

Undang-Undang No. 20 Tahun 2003 Tentang

Sistem Pendidikan Nasional pasal 26 ayat (3) menyatakan bahwa: Pendidikan nonformal meliputi pendidikan kecakapan hidup, pendidikan anak usia dini, pendidikan kepemudaan, pendidikan pemberdayaan perempuan, pendidikan keaksaraan, pendidikan keterampilan dan pelatihan kerja, pendidikan kesetaraan, serta pendidikan lain yang ditujukan untuk mengembangkan kemampuan peserta didik.

Program Keaksaraan Fungsional merupakan bentuk pelayanan Pendidikan Luar Sekolah (PLS) yang bertujuan untuk membelajarkan warga masyarakat penyandang buta aksara, agar memiliki kemampuan menulis, membaca, berhitung, dan menganalisis yang berorientasi pada kehidupan sehari-hari dengan memanfaatkan potensi yang ada di lingkungan sekitarnya, sehingga peserta didik dan masyarakat dapat meningkatkan mutu dan taraf hidupnya.

Program Keaksaraan Fungsional perlu direncanakan dan dilaksanakan seoptimal mungkin agar memiliki manfaat dan berdampak secara luas dalam percepatan pemberantasan buta aksara dan pada gilirannya dapat meningkat-kan pendapatan masyarakat, mengurangi angka pengangguran, dan kemiskinan.

Masyarakat buta aksara adalah mereka yang belum memiliki kemampuan menulis, membaca, berhitung, dan keterampilan fungsional. Keaksaraan fungsional secara utuh memiliki karakteristik yang terkait dengan buta aksara, melek aksara, dan keaksaraan fungsional. Buta aksara dapat disebabkan

* Penilik, Dikpora Kota Palopo, Sulawesi Selatan karena tidak pemah mengakses pendidikan sama sekali, putus Sekolah Dasar atau Madrasah Ibtidaiyah kelas 1-3.

Menyadari pentingnya kompetensi membaca, menulis, dan berhitung (Calistung) bagi warga masyarakat yang masih buta aksara, diharapkan warga masyarakat yang masih buta aksara berpartisipasi aktif dalam mengikuti program Keaksaraan Fungsional yang telah didesain oleh pemerintah dengan tujuan membantu meningkatkan dan mengembangkan kemampuan, pengetahuan, keterampilan baca-tulishitung, dan keterampilan fungsional peserta didik.

Berdasarkan data BPS tahun 2003, tercatat penduduk buta aksara usia 10-44 tahun sebesar 4.410.627 orang. Data ini merupakan indikator rendahnya Sumber Daya Manusia (SDM) Indonesia (Depdiknas, 2005a:1). Akselerasi penuntasan buta aksara telah diupayakan pemerintah melalui program Pendidikan Untuk Semua (PUS) yang menargetkan penurunan jumlah buta aksara sebesar $15 \%$ hingga tahun 2015. Bahkan pemerintah saat ini menargetkan pencapaian penurunan buta aksara mencapai $5 \%$ pada tahun 2009. Indeks Pembangunan Manusia Indonesia (IPM) pada tahun 2004 berada pada peringkat 111 dari 177 negara dan salah satu indikatornya adalah tingkat buta aksara.

Program Keaksaraan Fungsional berpusat pada diri peserta didik, terutama berkaitan dengan minat dan kebutuhan khusus pada diri setiap peserta didik, maka penilaian pembelajaran dalam program keaksaraan fungsional mencakup penilaian awal, penilaian proses, dan penilaian hasil belajar. Masing-masing tahapan penilaian ini dapat dilaksanakan dengan prosedur dan 
tata cara sendiri namun saling berkaitan antara tahapan yang satu dengan yang lainnya.

Berdasarkan pemantauan, evaluasi, dan bimbingan penulis sebagai penilik PLS, penulis menilai bahwa masyarakat yang buta aksara secara umum hidup dalam kemiskinan, kebodohan, dan keterbelakangan, baik dalam bidang kesehatan, gizi, ekonomi, maupun pembangunan pada umumnya. Keadaan warga masyarakat yang buta aksara berada dalam keadaan yang memprihatinkan, kurang pengetahuan, belum bisa memahami syarat-syarat hidup dalam suatu tata kehidupan modern sehingga mereka sangat membutuhkan pembinaan, bimbingan, dan pemberdayaan menghadapi kehidupan yang semakin kompetitif.

Pemerintah Kota Palopo pada tanggal 2 Mei 2006 melakukan pencanangan Kota Palopo bebas buta aksara tahun 2007, kemudian ditindak-lanjuti dengan penandatanganan MOU antara Dinas Pendidikan, Pemuda, dan Olah Raga dengan Universitas Cokroaminto Palopo dalam rangka percepatan pemberantasan buta aksara bagi warga masyarakat Kota Palopo.

Bimbingan teknis bagi tutor keaksaraan fungsional dan workshop peningkatan kompetensi tutor KF dilakukan bekerja sama dengan Forum Komunikasi Tutor Keaksaraan Fungsional Kota Palopo. Berdasarkan pemantauan, penilaian, dan bimbingan penilik PLS, bahwa langkah-langkah tersebut berpengaruh terhadap percepatan pencapaian tujuan pemberantasan buta aksara khususnya di Kecamatan Wara Utara Kota Palopo, menuju pendidikan nonformal yang berkualitas.

Tutor keaksaraan fungsional berkewajiban untuk: (1) membimbing peserta didik dalam setiap proses pembelajaran, menyiapkan sarana dan prasarana belajar yang diperlukan; (2) memotivasi peserta didik dan menjamin kelangsungan kelompok belajar dan membina jaringan kerja dengan berbagai organisasi yang terkait dan tokoh masyarakat; (3) melakukan evaluasi perkembangan peserta didik dan melaporkan kepada penyelenggara program; dan (4) memfasilitasi kelompok belajar untuk mengadakan jaringan kerja lokal dengan berbagai instansi terkait.

Penelitian ini dilakukan untuk mencari solusi efektif terhadap pembinaan dan peningkatan kompetensi para tutor keaksaraan fungsional. Dengan demikian program Pemerintah mengenai percepatan pemberantasan buta aksara dapat berdayaguna dan berhasilguna khususnya di Kecamatan Wara Utara Kota Palopo Provinsi Sulawesi Selatan.

\section{Rumusan Masalah}

Berdasarkan latar belakang, maka rumusan masalah yang akan dikaji dalam penelitian ini adalah: "Bagaimana kompetensi tutor keaksaraan fungsional dalam pengelolaan pembelajaran di Kecamatan Wara Utara Kota Palopo Provinsi Sulawesi Selatan ?".

\section{Tujuan Penelitian}

Adapun tujuan dari penelitian ini adalah untuk mengetahui kompetensi tutor keaksaraan fungsional dalam pengelolaan pembelajaran di Kecamatan Wara Utara Kota Palopo Provinsi Sulawesi Selatan.

\section{Manfaat Penelitian}

Adapun manfaat hasil penelitian ini adalah sebagai berikut.

1. Sebagai bahan pertimbangan bagi lembaga dan instansi terkait dalam mengambil keputusan dan kebijakan terhadap perekrutan tutor program keaksaraan fungsional.

2. Sebagai bahan informasi dan evaluasi bagi tutor keaksaraan fungsional, Pusat Kegiatan Belajar Masyarakat (PKBM), dan pengelola program keaksaraan fungsional dalam rangka percepatan penuntasan buta aksara.

3. Sebagai bahan rujukan dan pertimbangan bagi para tutor dalam pelaksanaan proses belajar mengajar program keaksaraan fungsional menuju pendidikan nonformal yang mandiri dan bermartabat.

4. Sebagai implementasi pengembangan profesi bagi penulis dalam mengkaji secara ilmiah tentang pengelolaan pembelajaran tutor keaksaraan fungsional menuju Pendidikan Luar Sekolah yang berkualitas. 


\section{Program Keaksaraan Fungsional}

Keaksaraan fungsional merupakan suatu pendekatan atau cara untuk mengembangkan kemampuan seseorang dalam menguasai dan menggunakan keterampilan menulis, membaca, berhitung, mengamati, dan menganalisa yang berorientasi pada kehidupan sehari-hari serta memanfaatkan potensi yang ada di lingkungan sekitarnya (Buku pedoman tutor KF, 1998:2)

Untuk memahami pengertian keaksaraan fungsional secara integral dan komprensif, perlu memahami beberapa istilah yang terkait dengan program keaksaraan fungsional, yaitu: (1) buta aksara murni, adalah penduduk yang sama sekali tidak bisa membaca, menulis, dan berhitung dengan sistem aksara apapun juga; (2) buta aksara, untuk konteks Indonesia buta aksara diasumsikan sebagai buta aksara latin dan angka arab, buta bahasa Indonesia, dan buta pengetahuan dasar; (3) melek aksara, ditafsirkan sebagai melek aksara latin dan angka arab, melek bahasa Indonesia, dan pengetahuan dasar; dan (4) keaksaraan fungsional.

\section{Tujuan Program Keaksaraan Fungsional}

Dalam buku Pedoman Tutor Kelompok Belajar Keaksaraan Fungsional tujuan program keaksaraan fungsional adalah diharapkan peserta didik: (1) bisa meningkatkan pengetahuan membaca, menulis, dan berhitung serta keterampilan fungsional untuk meningkatkan taraf hidupnya; (2) menggali potensi dan sumber-sumber kehidupan yang ada dilingkungan sekitar peserta didik, untuk memecahkan masalah keaksaraannya (Direktorat Pendidikan Masyarakat, 2003:1)

Sedangkan dalam buku Penyelenggaraan Program Keaksaraan Fungsional (2005: 8-9) tujuan program keaksaraan fungsional adalah dalam rangka memenuhi amanat konstitusi agar semua warga negara buta aksara memiliki kemampuan dasar baca-tulishitung, sehingga mampu: (1) membuka wawasan untuk mencari sumber-sumber kehidupannya; 2) melaksanakan kehidupan sehari-hari secara efektif dan efesien; (3) mengunjungi dan belajar pada lembaga yang diperlukan; (4) memecahkan masalah keaksaraan dalam kehidupannya sehari-hari; dan (5) menggali, mempelajari pengetahuan, keterampilan, dan sikap pembaharuan untuk meningkatkan mutu dan taraf hidupnya serta ikut berpartisipasi dalam pemba-ngunan.

\section{Prinsip Penyelenggaraan Program Keaksaraan Fungsional}

Penyelenggaraan program keaksaraan fungsional menggunakan empat prinsip utama yang perlu diperhatikan adalah

1. Konteks lokal, artinya kegiatan belajar mengajar yang dilaksanakan, berdasarkan pada minat dan kebutuhan peserta didik, serta potensi yang ada di sekitarnya. Konteks lokal mengacu pada konteks sosial lokal dan kebutuhan khusus dari setiap peserta didik dan masyarakat sekitarnya. Tutor bersama peserta didik melakukan observasi lingkungan sekitarnya untuk mencari dan mengumpulkan informasi untuk pengelolaan kegiatan pembelajaran. Observasi lingkungan bertujuan untuk mengidentifikasi minat dan kebutuhan serta menemukan masalah yang dihadapi mereka.

2. Desain lokal, tutor bersama peserta didik perlu merancang sendiri kegiatan belajarnya di kelompok belajar berdasarkan minat, kebutuhan, masalah, kenyataan, dan potensi tempat penyelenggaraan program keaksaraan fungsional. Rancangan pembelajarannya bersifat fleksibel, mudah dimodifikasi, diganti, dan ditambah. Tutor bersama peserta didik merancang dan menetapkan kurikulum sendiri. Proses penyusunan disain pembelajaran bisa dilakukan melalui diskusi antara tutor dengan peserta didik untuk menetapkan: (a) pokok bahasan yang ingin dipelajari dan tujuannya; (b) prioritas pokok bahasan yang diinginkan; (c) cara atau strategi pembelajaran yang akan digunakan; d) langkahlangkah kegiatan yang perlu dilakukan, agar tujuan pembelajaran tercapai; (e) Jadwal kegiatan pembelajaran; dan f) kesepakatan belajar dan mengajar.

3. Proses partisipatif, dilakukan dengan menyusun perencanaan, pelaksanaan, dan evaluasi penyelenggaraan program keaksaraan fungsional. Strategi partisipatif diimplementasikan dengan cara 
melibatkan semua pihak, termasuk tutor dan peserta didik aktif dalam setiap tahap kegiatan pembelajaran. Kegiatan partisipatif dapat dilakukan oleh tutor dengan memberikan stimulasi terhadap peserta didik untuk berdiskusi dengan cara membuat pertanyaan, melakukan wawancara tentang pengalaman peserta didik, menulis cerita lokal, membuat peta masalah lingkungan, membuat gambar, dan sebagainya.

4. Fungsionalisasi hasil belajar, kriteria utama dalam menentukan keberhasilan program keaksaraan fungsional adalah dengan cara meningkatkan kemampuan dan keterampilan setiap peserta didik dalam memanfaatkan dan memfungsikan keaksaraan atau hasil belajarnya dalam kegiatan sehari-hari sehingga mereka dapat meningkatkan mutu dan taraf hidupnya.

\section{Tolak Ukur Keberhasilan Program Keaksaraan Fungsional}

Orientasi program keaksaraan fungsional adalah membantu peserta didik agar memiliki kemampuan baca-tulis-hitung dan mengembangkan kemampuan fungsional yang dibutuhkan dalam kehidupan sehari-hari. Dalam buku Penyelenggaraan Program Keaksaraan Fungsional, Direktorat Jenderal Pendidikan Luar Sekolah dan Pemuda, Direktorat Tenaga Teknis (2005:11) dikemukakan kemampuan peserta didik yang menjadi tolak ukur keberhasilan program keaksaraan fungsional meliputi :

1. kemampuan fungsional untuk keperluan individu;

2. kemampuan fungsional untuk membantu anakanaknya;

3. kemampuan fungsional untuk aktualisasi diri;

4. kemampuan fungsional berkaitan dengan pekerjaan warga belajar;

5. kemampuan fungsional berkaitan dengan sosial kemasyarakatan;

6. kemampuan fungsional berkaitan dengan pendidikan;

7. kemampuan fungsional berkaitan dengan pengelolaan kelompok belajar; dan

8. kemampuan berhitung fungsional berkaitan dengan kehidupan sehari-hari.

\section{Pengelolaan Pembelajaran Keaksaraan Fungsional}

Pengelolaan atau pengaturan pembelajaran keaksaraan fungsional pada dasamya ada dua macam yaitu: pengelolaan edukatif, merupakan kegiatan penataan persiapan, pelaksanaan pembelajaran dan pelaksanaan penilaian, dan pengelolaan administratif. Sedangkan prinsip pengelolaan pembelajaran keaksaraan fungsional adalah (a) menyeluruh terhadap aspek pengelolaan edukatif dan administratif; (b) memiliki nilai yang berarti; (c) konsisten dan berkesinambungan, (d) dilaksanakan secara partisipatif; dan (e) menumbuhkan sikap inisiatif dan kreatif untuk mempercepat pencapaian tujuan akhir pembelajaran (Direktorat Tenaga Teknis, 2005:6).

Ada tiga proses pengelolaan pembelajaran keaksaraan fungsional sebagai berikut.

1. Persiapan Pembelajaran

a. Identifikasi kemampuan awal keaksaraan calon peserta didik, sekaligus menjaring kebutuhan belajar dan potensi pendukungnya.

b. Mengelompokkan calon peserta didik.

c. Mengengelompokkan kebutuhan belajar apa yang paling dibutuhkan berdasarkan potensi yang ada.

d. Penyusunan program belajar.

2. Pelaksanaan Pembelajaran

Langkah Pembelajaran

a. Pelajari kembali SAP yang telah disusun.

b. Mengabsen peserta didik.

c. Pembelajaran dilakukan tahap demi tahap.

d. Mencatat perkembangan calistung peserta didik.

e. Melakukan penilaian setiap akhir pembelajaran.

3. Administrasi Pembelajaran

a. Administrasi peserta didik, daftar kecakapan awalnya, perkembangan diisi setiap pertemuan, catatan harian, dan buku kamus peserta didik.

b. Administrasi tutor, matrik gagasan pembelajaran, program pembelajaran seluruh topik, kesepakatan pembelajaran, satuan acara pembelajaran, absensi, dan buku penilaian hasil belajar peserta didik.

c. Administrasi lainnya, hasil karya peserta didik seperti koran dinding, poster abjad, dan lain-lain.

\section{Penilaian Hasil Pembelajaran}

Penilaian adalah upaya seksama untuk mengumpulkan, menyusun dan mengolah fakta, data dan informasi untuk menyimpulkan harga, nilai, kegunaan, dan kinerja mengenai sesuatu.

Penilaian standar kompetensi bagi peserta didik meliputi dua bentuk alat penilaian, yaitu: (1) tes, bentuk tes adalah need assessment, tes diagnostik, tes formatif dan tes sumatif; dan (2) nontes, penilaian nontes berupa penilaian sikap dan kemampuan motorik, maka penilaiannya dilakukan dengan pengamatan (Diktentis, 2005:8) 
Pengelolaan penilaian pembelajaran difokuskan pada alur proses :

1. pengelolaan penilaian sebelum atau awal pembelajaran;

2. pengelolaan penilaian selama proses pembelajaran; dan

3. pengelolaan penilaian akhir pembelajaran.

\section{Kerangka Berpikir}

Berdasarkan kajian pustaka yang telah dikemukakan, maka disimpulkan bahwa keaksaraan fungsional adalah pendekatan pembelajaran baca, tulis, dan berhitung yang terintegrasi dengan keterampilan usaha berdasarkan kebutuhan potensi warga belajar dan sumber daya tenaga yang ada.

Program keaksaraan fungsional bertujuan untuk memberdayakan warga belajar agar mampu membaca, menulis, berhitung, dan berbahasa Indonesia yang baik dan benar. Prinsip pembelajarannya adalah (a) pembelajaran untuk orang dewasa; (b) terkait dengan konteks lokal; (c) menggunakan desain lokal, bersifat partisipatif, bersifat fungsional, dan penilaian sebagai alat pembelajaran.

Berdasarkan pemantauan, evaluasi, dan bimbingan penulis di Kecamatan Wara Utara Kota Palopo sebagai penilik PLS penulis menilai bahwa masyarakat yang buta aksara cenderung hidupnya berada di bawah garis kemiskinan, kebodohan, dan keterbelakangan.

Keadaan warga masyarakat buta aksara berada dalam keadaan yang membutuhkan perhatian dari berbagai pihak dan membantu mereka agar dapat mengantisipasi ketidak-berdayaannya. Kepedulian, bimbingan, motivasi, pencerahan hati, dan pikiran mereka butuhkan dalam menghadapi kehidupan yang semakin kompetitif.

Tutor berfungsi sebagai pengajar sekaligus pendidik, pemegang peran penting dalam pengimplementasian bahan pembelajaran, baik dalam rancangan maupun aplikatifnya, sehingga keberhasilan dan keaktifan peserta didik dalam proses pembelajaran ditentukan dan dipengaruhi oleh sejauh mana kompetensi tutor dalam mengajar dan mendidik sehingga akselerasi pemberantasan buta aksara bisa diwujudkan dalam waktu yang relatif singkat.

Kerja keras dan kebersamaan sangat dibutuhkan dalam membina para warga masyarakat yang masih buta huruf. Pembinaan dan kepedulian komprehensif dari para tenaga pendidikan dan kependidikan dibutuhkan mereka agar salah satu demensi Rencana Aksi Nasional Pendidikan Keaksaraan tahun 2015 yaitu tercapainya peningkatan sebesar $50 \%$ pada tingkat keaksaraan orang dewasa yaitu kelompok 15 tahun ke atas.

Kompetensi tutor memiliki peran yang sangat signifikan dalam pengelolaan pembelajaran keaksaraan fungsional. Kerangka berpikir penelitian digambarkan sebagai berikut.

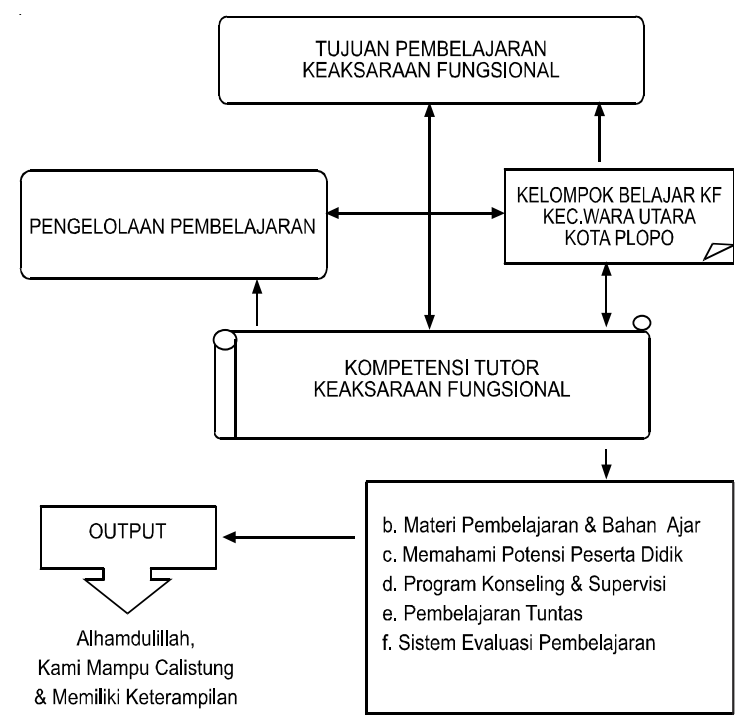

Gambar: Kerangka Pikir

\section{METODOLOGI PENELITIAN}

\section{Tempat dan Waktu Penelitian}

Tempat Penelitian

Penelitian ini dilaksanakan di Kelompok Belajar

Program Keaksaraan Fungsional yang ada di PKBM PAHLAWAN, AL-AMIN, dan LAPAS Kecamatan Wara Utara Kota Palopo provinsi Sulawesi Selatan.

\section{Waktu Penelitian}

Penelitian ini mulai dilaksanakan sejak tanggal 1 Januari sampai dengan 18 Mei 2006.
Jenis Penelitian

Penelitian ini bersifat penelitian deskriptif, yaitu dengan memberikan gambaran secara kuantitatif terhadap perasalahan yang diajukan dan disusun dalam bentuk persentase dan frekuensi.

\section{Variabel Penelitian}

Adapun variabel yang diperhatikan dalam penelitian ini adalah "Kompetensi Tutor Keaksaraan Fungsional dalam Pengelolaan Pembelajaran”. 
Definisi Operasional Variabel

Untuk memberikan gambaran yang jelas dan menghindari interpretasi yang keliru terhadap variabel penelitian maka diadakan pendefinisian variabel sebagai berikut.

1. Kompetensi atau kemampuan adalah klasifikasi yang berupa kecakapan, potensi, dan kesanggupan baik konsep teoritis dan keterampilan dalam memberikan pelayanan pembelajaran bagi peserta didik.

2. Tutor adalah seseorang yang melakukan pembimbingan pembelajaran atau orang yang memfasilitasi proses pembelajaran di kelompok belajar.

3. Keaksaraan fungsional adalah bentuk layanan Pendidikan Luar Sekolah untuk membelajarkan warga masyarakat penyandang buta aksara, agar memiliki kemampuan membaca, menulis, berhitung, dan keterampilan fungsional yang berorientasi pada kehidupan sehari-hari dengan memanfaatkan potensi lokal.

4. Pengelolaan pembelajaran adalah kemampuan dan keterampilan khusus untuk melakukan proses edukatif dan administratif terhadap peserta didik untuk mencapai hasil belajar yang maksimal atau kemampuan melakukan interaksi antara warga belajar dengan tutor, atau dengan komponenkomponen pembelajaran lainnya seperti materi belajar, media, lingkungan, dan lain-lain.

\section{Populasi dan Sampel}

Populasi

Menurut Mardalis (1993) populasi adalah semua individu yang menjadi sumber pengambilan sampel. Sedangkan Suharsimi Arikunto (1998:115) menyatakan populasi adalah keseluruhan obyek penelitian.

Berdasarkan batasan-batasan di atas, maka dapat dipahami bahwa populasi adalah semua individu yang menjadi sarana dalam penelitian. Oleh karena itu, disimpulkan bahwa yang menjadi populasi penelitian ini adalah seluruh tutor keaksaran fungsional yang telah memiliki pengalaman mengajar di program keaksaraan fungsional di Kecamatan Wara Utara Kota Palopo.

Populasi penelitian ini terdiri atas delapan tutor keaksaraan fungsional, maka penelitian ini adalah penelitian populasi, berdasarkan pendapat Suharsimi Arikunto (1998: 117) Penelitian populasi hanya dapat dilakukan bagi terhingga dan subjeknya tidak terlalu banyak.

Penelitian ini adalah penelitian populasi yang secara otomatis menggunakan sampel total dari populasi itu sendiri, yaitu tutor yang telah memiliki pengalaman mengajar pada program keaksaraan fungsional yang ada di Kecamatan Wara Utara kota Palopo.

\section{Teknik Pengumpulan Data}

Teknik pengumpulan data penelitian ini menggunakan teknik pengumpulan data melalui instrumen berupa angket, wawancara, dan dokumentasi.

\section{Angket}

Cara ini digunakan untuk memperoleh data primer. Angket digunakan untuk mengukur tingkat kompetensi tutor dalam pengelolaan pembelajaran keaksaraan fungsional yang terdiri atas lima aspek yaitu: (1) materi pembelajaran dan pemanfaatan bahan ajar indikator yang diukur dengan (a) kemampuan menyusun materi pembelajaran keaksaraan fungsional yang berorientasi kepada empat prinsip utama pembelajaran keaksaraan fungsional yaitu: konteks lokal, desain lokal, proses partisipatif, dan pemanfaatan hasil belajar; (b) kemampuan menyusun rencana pembelajaran, menjabarkan materi pelajaran ke uraian materi, pengelolaan proses pembelajaran kontekstual sesuai kebutuhan peserta didik, dan memahami subtansi materi yang diajarkan; (c) kemampuan pencapaian tujuan pembelajaran membaca, menulis, dan berhitung ke dalam materi pelajaran dan media pembelajaran tematik KF; (d) kemampuan memilih dan menerapkan strategi, metode, dan teknik pembelajaran berdasarkan materi serta kesesuaian dengan alokasi waktu dengan lingkup materi; (e) kemampuan menjabarkan materi pokok menjadi bahan ajar pembelajaran membaca, menulis, berhitung, dan keterampilan fungsional sesuai dengan ciri-ciri bahan KF yaitu: relevansi, terformulasikan, disiplin ilmu, dan efektifitas tujuan; (f) kemampuan memahami sifat dan jenis bahan ajar seperti bahan ajar yang bersifat memotivasi, pengajaran, dan bahan ajar lanjutan; (g) kemampuan menjabarkan jenis materi pembelajaran calistung dan keterampilan fungsional menjadi bahan ajar; (h) kemampuan menemukan tingkat kedalaman dan kesulitan bahan ajar serta ruang lingkupnya; (i) kemampuan menentukan urutan penyajian materi pembelajaran membaca, menulis, dan berhitung; dan (j) kemampuan berkreatifitas membuat alternatif bahan ajar yang murah, mudah, menyenangkan, dan menimbulkan kesan bagi peserta didik.

(2) Memahami potensi peserta didik, indikator yang diukur dengan: (a) kemampuan mengidentifikasi potensi membaca, menulis, berhitung, dan keterampilan fungsional peserta didik; (b) kemampuan mengetahui 
minat, kebutuhan, dan keadaan peserta didik; (c) kemampuan memahami perkembangan kemampuan membaca, menulis, berhitung, dan keterampilan fungsional peserta didik, kemudian melakukan cheklist kemajuan; (d) kemampuan mendiagnosa kesenangan peserta didik terhadap proses pemanfaatan pendekatan kontekstual, partisipatif, komunikatif, interaktif, dan teori pembelajaran menyenangkan (learning for fun) secara andragogik; (e) kemampuan membimbing, memotivasi dan mendidik peserta didik dalam berdiskusi; (f) kemampuan mendeteksi kesulitan belajar peserta didik dan mengelompokkan berdasarkan kemampuannya; dan (g) kemampuan melakukan kesepakatan pembelajaran dan pcmbentukan kelompok menulis, membaca, dan berhitung peserta didik.

(3) Program konseling dan supervisi, indikator yang diukur adalah: (a) kemampuan menyusun bahan konseling dan supervisi; (b) kemampuan melaksanakan program konseling dan supervisi; (c) kemampuan mengatur frekuensi pelaksanaan konseling dan supervisi pada saat proses dan setelah proses pembelajaran; (d) kemampuan memanfaatkan waktu yang ada dengan pelaksanaan konseling dan supervisi; (e) kemampuan memilih fasilitas pendukung program konseling dan supervisi, dan (f) kemampuan memanfaatkan hasil konseling dan supervisi.

(4) Pembelajaran tuntas, indikator yang diukur adalah: (a) kemampuan menerapkan dan memahami strategi pembelajaran dengan pendekatan andragogik; (b) kemampuan menjabarkan kompetensi dasar ke dalam rencana pembelajaran dan kemampuan memonitor seluruh pekerjaan peserta didik; (c) kemampuan mentransfer materi pembelajaran membaca, menulis, berhitung, dan keterampilan fungsional kepada peserta didik; (d) kemampuan memahami tingkat ketercapaian dan ketuntasan pembelajaran bagi peserta didik dari setiap item materi pembelajaran calistung dan keterampilan fungsional; (e) kemampuan menyajikan materi dalam metode yang bervariasi serta kesiapan melaksanakan program layanan remedial; dan (f) kemampuan melaksanakan program layanan pengayaan dan percepatan ketuntasan belajar.

(5) Sistem evaluasi pembelajaran, indikator yang diukur adalah: (a) kemampuan memahami sistem evaluasi pembelajaran keaksaraan fungsional secara komprehensif; (b) kemampuan melakukan penilaian kemampuan awal membaca, menulis, berhitung, dan keterampilan fungsional bagi peserta didik, untuk pencapaian tujuan pembelajaran keaksaraan fungsional; (c) kemampuan menyusun bahan evaluasi terhadap peserta didik yang meliputi tujuan penilaian, ruang lingkup, waktu, tata cara, analisis hasil, dan tindak lanjut penilaian; (d) kemampuan melakukan evaluasi setelah proses pembelajaran dan tindak lanjut hasil evaluasi; dan (e) kemampuan mengukur keberhasilan pembelajaran program keaksaraan fungsional secara integral dan pengimplementasian hasil evaluasi.

Kelima aspek di atas dilengkapi dengan daftar pernyataan dan instrumen tersebut disebar ke dalam lima item pernyataan yang berjumlah tiga puluh lima (35) butir soal dalam bentuk skala likert, dengan lima macam kategori pilihan yaitu Sangat Mampu (SM) bernilai 5, Mampu (M) bernilai 4, Netral (N) bernilai 3, Tidak Mampu (TM) bernilai 2, dan Sangat Tidak Mampu (STM) bernilai 1.

\section{Wawancara}

Teknik wawancara yang penulis lakukan berfungsi sebagai kroscek terhadap kebenaran dan kesesuaian angket yang telah disi oleh tutor dengan kompetensinya. Wawancara penulis lakukan demi memperoleh data faktual dan akurat dari para tutor keaksaraan fungsional sebagai objek penelitian.

\section{Dokumentasi}

Teknik dokumentasi digunakan untuk mengumpulkan data sekunder melalui kajian pustaka dengan membaca berbagai literatur dan sumber informasi lainnya yang berhubungan dengan penelitian ini.

Data yang diperoleh dari teknik dokumentasi adalah populasi dan sampel penelitian, tempat penelitian, dan data yang berkaitan dengan perkembangan pelaksanaan program Keaksaraan Fungsional di Kecamatan Wara Utara Kota Palopo Provinsi Sulawesi Selatan.

\section{Teknik Analisis Data}

Data hasil penelitian, selanjutnya dianalisis dengan menggunakan analisa deskriptif yang dilengkapi dengan tabel distribusi frekuensi, prosentase, histogram, dan phie graf. Keseluruhan data kuantitatif penelitian ini diolah dan dianalisis dengan menggunakan program komputer SPSS. Dalam penentuan kategori dimensi penelitian dilakukan perhitungan rata-rata ideal dan simpangan baku ideal dengan rumus sebagai berikut. 


$$
\begin{aligned}
& M i=\frac{N i t+N i r}{2} \\
& \text { (Suprapto, 1999) } \\
& S d i=\frac{N i t-N i r}{7}
\end{aligned}
$$

Tabel 1. Batas kelas interval menurut kategori berpedoman pada rumus di atas

\begin{tabular}{|c|c|}
\hline KATEGORI & BATAS KELAS \\
\hline Baik/Tinggi & $>(\mathrm{M}+1,5 \mathrm{Sdi})$ \\
\hline Cukup & M sampai $(\mathrm{M}+1,5 \mathrm{Sdi})$ \\
\hline Kurang & $(\mathrm{M}-1,5$ Sdi $)$ sampai $\mathrm{M}$ \\
\hline Rendah & $<(\mathrm{M}-1,5$ Sdi $)$ \\
\hline
\end{tabular}

\section{HASIL PENELITIAN}

Hasil analisis data kompetensi tutor keaksaraan fungsional dalam pengelolaan pembelajaran di Kecamatan Wara Utara Kota Palopo Provinsi Sulawesi Selatan yang dikelola melalui program komputer SPSS sebagai berikut.

1. Materi Pembelajaran dan Pemanfaatan Bahan Ajar

Berdasarkan hasil analisis deskriptif data observasi yang berkaitan dengan aspek materi pembelajaran dan bahan ajar, nilai rata-rata (mean) adalah 37,90 . modus yaitu 37,00 , median yaitu 37,50 , standar deviasi yaitu 3,48 , nilai minimum 33,00 dan nilai maksimum adalah 43,00. Selanjutnya distribusi skor aspek materi pembelajaran dan pemanfaatan bahan ajar tersebut dapat dilihat pada tabel 2 berikut.

Tabel 2. Distribusi frekuensi dan prosentase skor aspek materi pembelajaran dan pemanfaatan bahan ajar

\begin{tabular}{|c|l|l|l|l|l|}
\hline No. & Interval Skor & Kategori & Frekuensi & Prosentase & $\begin{array}{l}\text { Prosentase } \\
\text { Kumulatif }\end{array}$ \\
\hline 1. & $43.12-50,00$ & Baik/Tinggi & - & - & 50,0 \\
\hline 2. & $37.90-43.11$ & Cukup & 4 & $50 \%$ & 100,0 \\
\hline 3. & $32.68-37.89$ & Kurang & 4 & $50 \%$ & \\
\hline 4. & $30.00-32.67$ & Rendah & - & - & \\
\hline & Jumlah & & 8 & & \\
\hline
\end{tabular}

Untuk lebih jelasnya gambaran tentang tingkat kompetensi tutor pada aspek materi pembelajaran dan pemanfaatan bahan ajar dapat dilihat pada gambar berikut.

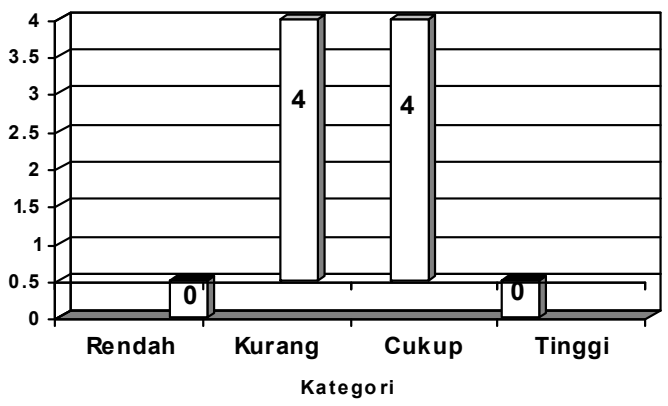

Gambar 1. Aspek materi pembelajaran dan pemanfaatan bahan ajar
Dengan memperhatikan rata-rata skor kompetensi tutor pada aspek materi pembelajaran dan pemanfaatan bahan ajar dari 8 responden, terdapat 4 responden berada pada kategori cukup atau sekitar $50 \%$, dan 4 responden berada pada kategori kurang atau 50\%. Tidak ada responden yang berada pada kategori rendah dan kategori kurang.

Jadi dapat disimpulkan bahwa kompetensi tutor keaksaraan fungsional dalam pengelolaan pembelajaran pada aspek materi pembelajaran dan pemanfaatan bahan ajar secara umum berada pada kategori cukup, karena dari empat responden yang memperoleh nilai kurang terdapat dua responden yang memperoleh nilai 37 , hal tersebut bisa dilihat pada lampiran analisis data.

b. Memahami Potensi Peserta Didik

Berdasarkan hasil analisis deskriptif data observasi yang berkaitan dengan aspek memahami potensi peserta didik, nilai rata-rata (mean) adalah 26,10 modus yaitu 24,00 , median yaitu 26,00 , standar deviasi yaitu 2,47 , nilai minimum 23,00 dan nilai maksimum adalah 30,00. Selanjutnya distribusi skor aspek memahami potensi peserta didik tersebut dapat dilihat pada tabel 3 berikut.

Tabel 3. Distribusi frekuensi dan prosentase skor aspek memahami potensi peserta didik

\begin{tabular}{|c|c|c|c|c|c|}
\hline No. & Interval Skor & Kategori & Frekuensi & Prosentase & $\begin{array}{c}\text { Prosentase } \\
\text { Kumulatif }\end{array}$ \\
\hline 1. & $29.80-35.00$ & Baik/Tinggi & 1 & 12,5 & 12,5 \\
\hline 2. & $26.10-29.79$ & Cukup & 2 & 25,0 & 87,5 \\
\hline 3. & $22.40-26.09$ & Kurang & 5 & 62,5 & 100,0 \\
\hline 4. & $20.00-22.39$ & Rendah & - & - & \\
\hline & Jumlah & & 8 & & \\
\hline
\end{tabular}

Sumber: Hasil pengolahan data 2006

Untuk lebih jelasnya gambaran tentang tingkat kompetensi tutor pada aspek memahami potensi peserta didik dapat dilihat pada gambar berikut. 
Kompetensi Tutor Keaksaraan Fungsional..

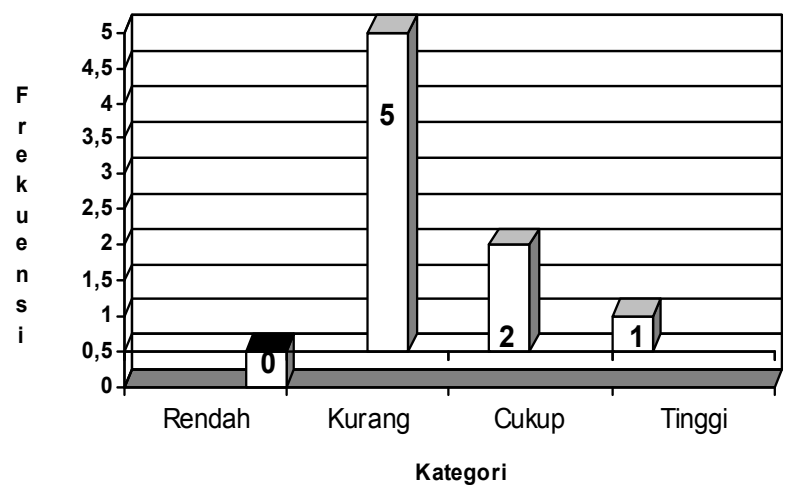

Gambar 2. Aspek memahami potensi peserta didik

Dengan memperhatikan rata-rata skor kompetensi tutor pada aspek memahami potensi peserta didik dari 8 responden, terdapat 2 responden berada pada kategori cukup atau sekitar 25,5\%, 5 responden berada pada kategori kurang atau sekitar $62,5 \%$, dan 1 responden berada pada kategori tinggi atau sekitar $12,5 \%$, tidak ada responden yang berada pada kategori rendah.

Jadi dapat disimpulkan bahwa kompetensi tutor keaksaraan fungsional dalam pengelolaan pernbelajaran pada aspek kemampuan memahami potensi peserta didik tergolong kurang.

c. Program Konseling dan Supervisi

Berdasarkan hasil analisis deskriptif data observasi yang berkaitan dengan program konseling dan supervisi, nilai rata-rata (mean) adalah 19.10, modus yaitu 20.00 , median yaitu 20,00 , standar deviasi yaitu 1,64 , nilai minimum 16,00 dan nilai maksimum adalah 21,00 . Selanjutnya distribusi skor program konseling dan supervisi tersebut dapat dilihat pada tabel 4. berikut.

Tabel 4. Distribusi frekuensi dan prosentase skor program konseling dan supervisi

\begin{tabular}{|c|l|c|c|c|c|}
\hline No. & Interval Skor & Kategori & Frekuensi & Prosentase & $\begin{array}{c}\text { Prosentase } \\
\text { Kumulatif }\end{array}$ \\
\hline 1. & $21.56-30.00$ & Baik/Tinggi & - & - & 62,5 \\
\hline 2. & $19.10-21.55$ & Cukup & 5 & 62,5 & 87,5 \\
\hline 3. & $16.64-19.09$ & Kurang & 2 & 25,0 & 100.0 \\
\hline 4. & $10.00-16.63$ & Rendah & 1 & 12,5 & \\
\hline & Jumlah & & 8 & & \\
\hline
\end{tabular}

Sumber: Hasil pengolahan data 2006

Untuk lebih jelasnya gambaran tentang tingkat kompetensi tutor pada program konseling dan supervisi dapat dilihat pada gambar berikut.

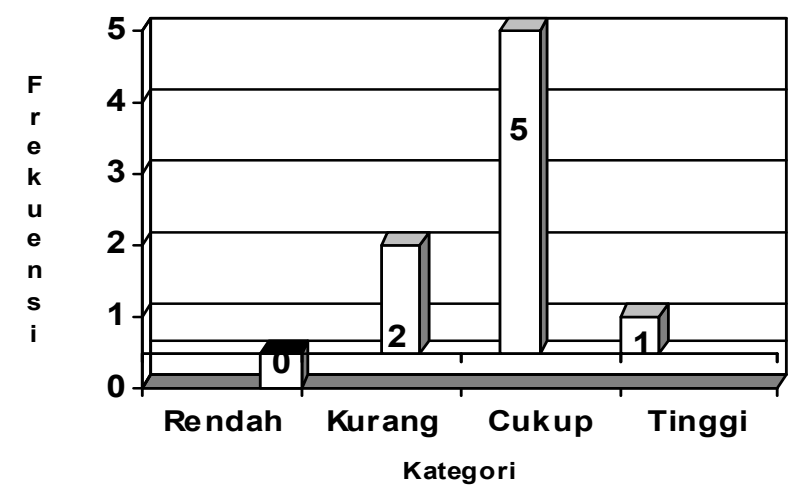

Gambar 3. Program konseling dan supervisi

Dengan memperhatikan rata-rata skor program konseling dan supervisi dari 8 responden, terdapat 5 responden berada pada kategori cukup atau sekitar $62,5 \%, 2$ responden berada pada kategori kurang atau sekitar $25 \%$, dan 1 responden berada pada kategori rendah atau $12,5 \%$. tidak ada responden yang berada pada kategori tinggi.

Jadi dapat disimpulkan bahwa kompetensi tutor keaksaraan fungsional dalam pengelolaan pembelajaran pada program konseling dan supervisi tergolong cukup.

d. Pembelajaran Tuntas

Berdasarkan hasil analisis deskriptif data observasi yang berkaitan dengan aspek pembelajaran tuntas, nilai rata-rata (mean) adalah 21,60 modus yaitu 19,00 , median yaitu 22,00, standar deviasi yaitu 2,13 , nilai minimum 19.00 dan nilai maksimum adalah 25,00. Selanjutnya distribusi skor aspek pembelajaran tuntas tersebut dapat dilihat pada tabel berikut.

Tabel 5. Distribusi frekuensi dan prosentase skor aspek pembelajaran tuntas

\begin{tabular}{|l|l|l|l|l|l|}
\hline No. & Interval Skor & Kategori & Frekuensi & Prosentase & $\begin{array}{l}\text { Prosentase } \\
\text { Kumulatif }\end{array}$ \\
\hline 1. & $24.80-30.00$ & Baik/Tinggi & 1 & 12,5 & 50,0 \\
\hline 2. & $21.60-24.79$ & Cukup & 4 & 50,0 & 87,5 \\
\hline 3. & $18.40-21.59$ & Kurang & 3 & 37,5 & 100,0 \\
\hline 4. & $15.00-17.39$ & Rendah & - & - & \\
\hline & Jumlah & & 8 & & \\
\hline
\end{tabular}

Sumber: Hasil pengolahan data 2006

Untuk lebih jelasnya gambaran tentang tingkat kompetensi tutor pada aspek pembelajaran tuntas dapat dilihat pada gambar berikut. 


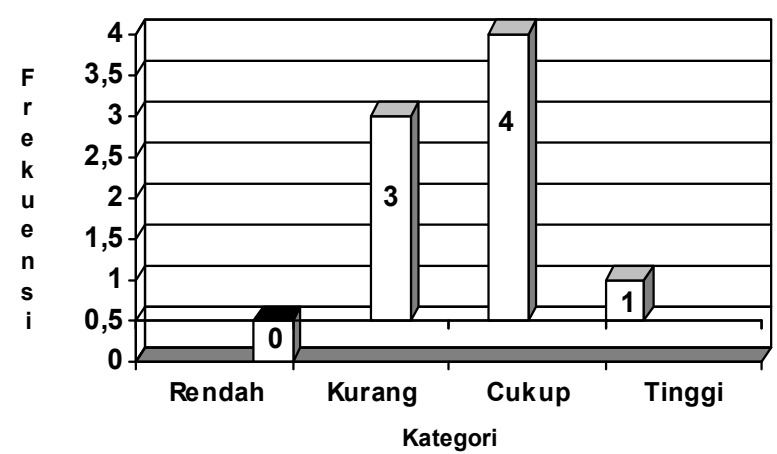

Gambar 4. Aspek pembelajaran tuntas

Dengan memperhatikan rata-rata skor aspek pembelajaran tuntas dari 8 responden, terdapat 4 responden berada pada kategori cukup atau sekitar $50 \%, 3$ responden berada pada kategori kurang atau sekitar $37,5 \%$, dan 1 responden berada pada kategori tinggi atau sekitar $12,5 \%$, tidak ada responden yang berada pada kategori rendah.

Jadi dapat disimpulkan bahwa kompetensi tutor keaksaraan fungsional dalam pengelolaan pembelajaran pada aspek pembelajaran tuntas tergolong cukup.

e. Sistem evaluasi pembelajaran

Berdasarkan hasil analisis deskriptif data observasi yang berkaitan dengan sistem evaluasi pembelajaran, nilai rata-rata (mean) adalah 18,90, modus yaitu 19,00, median yaitu 19,00, standar deviasi yaitu 2,47 , nilai minimum 16,00 dan nilai maksimum adalah 24,00. Selanjutnya distribusi skor sistem evaluasi pembelajaran tersebut dapat dilihat pada tabel 6 berikut.

Tabel 6. Distribusi frekuensi dan prosentase skor sistem evaluasi pembelajaran

\begin{tabular}{|l|l|l|l|l|l|}
\hline No. & Interval Skor & Kategori & Frekuensi & Prosentase & $\begin{array}{c}\text { Prosentase } \\
\text { Kumulatif }\end{array}$ \\
\hline 1. & $22.60-30.00$ & BaikTinggi & 1 & 12,5 & 50,0 \\
\hline 2. & $18.90-22.59$ & Cukup & 4 & 50,0 & 87,5 \\
\hline 3. & $15.20-18.89$ & Kurang & 3 & 37,5 & 100,0 \\
\hline 4. & $10.00-15.19$ & Rendah & - & - & \\
\hline & Jumlah & & 8 & & \\
\hline
\end{tabular}

Sumber: Hasil pengolahan data 2006

Untuk lebih jelasnya gambaran tentang tingkat kompetensi tutor sistem evaluasi pembelajaran dapat dilihat pada gambar berikut.

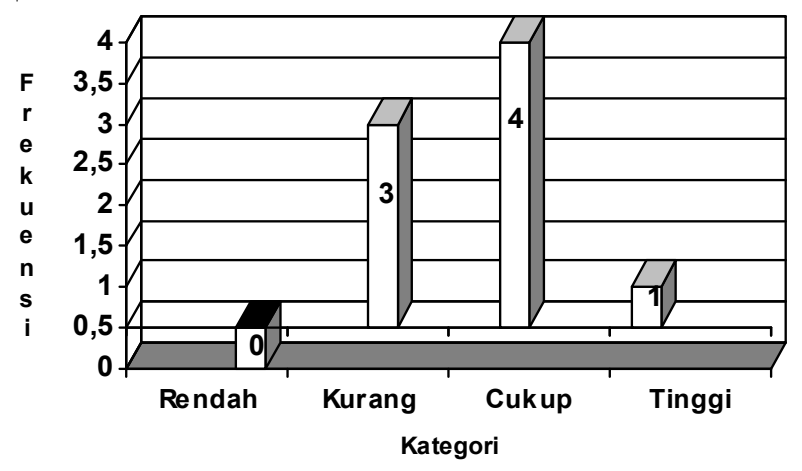

Gambar 5. Aspek sistem evaluasi pembelajaran

Dengan memperhatikan rata-rata skor sistem evaluasi pembelajaran dari 8 responden, terdapat 4 responden berada pada kategori cukup atau sekitar $50 \%, 3$ responden berada pada kategori kurang atau sekitar $37,5 \%$, dan 1 responden berada pada kategori tinggi atau sekitar $12,5 \%$, tidak ada responden yang berada pada kategori rendah.

Jadi dapat disimpulkan bahwa kompetensi tutor keaksaraan fungsional dalam pengelolaan pembelajaran pada sistem evaluasi pembelajaran tergolong cukup.

\section{Pembahasan}

Hasil analisis data di atas menunjukkan bahwa kompetensi tutor keaksaraan fungsional dalam pengelolaan pembelajaran pada aspek materi pembelajaran dan pemanfaatan bahan ajar berada pada kategori cukup, karena dari empat responden yang memperoleh nilai kurang terdapat dua responden yang memperoleh nilai 37 , dari 8 responden terdapat 4 atau $50 \%$ responden yang tergolong cukup dan 4 atau $50 \%$ responden yang tergolong kurang. Hal ini menunjukkan bahwa beberapa indikator dalam aspek materi pembelajaran dan pemanfaatan bahan ajar memiliki persentase relatif kecil. Di antaranya kemampuan pencapaian tujuan pembelajaran membaca, menulis, dan berhitung ke dalam materi pelajaran dan media pembelajaran tematik keaksaraan fungsional, kemampuan memilih dan menerapkan strategi, metode, dan teknik pembelajaran berdasarkan materi yang diajarkan serta kesesuaian alokasi waktu dengan lingkup materi, dan kemampuan menentukan urutan penyajian materi pembelajaran membaca, menulis, dan berhitung.

Berdasarkan hasil analisis data di atas, menunjukkan bahwa kompetensi tutor keaksaraan fungsional dalam pengelolaan pembelajaran pada aspek memahami potensi peserta didik tergolong kurang, yaitu dari 8 responden terdapat 5 atau sekitar $62.5 \%$ tutor 
yang memiliki kompetensi dalam kategori kurang. Hal ini disebabkan karena beberapa indikator dalam aspek memahami potensi peserta didik memiliki persentase relatif kecil. Diantaranya kemampuan mengetahui minat, kebutuhan, dan keadaan peserta didik, kemampuan mendiagnosa kesenangan peserta didik terhadap proses pemanfaatan pendekatan kontekstual, partisipatif, komunikatif, interaktif, dan teori pembelajaran menyenangkan (learning for fun) secara andragogik, dan kemampuan mendeteksi kesulitan belajar peserta didik. Berdasarkan pemantauan, evaluasi, dan bimbingan penilik PLS terhadap tutor keaksaraan fungsional menunjukkan bahwa salah satu indikator kegagalan tutor dalam mengelola pembelajaran keaksaraan fungsional adalah tutor kurang memahami potensi peserta didik.

Hasil analisis data di atas, menunjukkan bahwa kompetensi tutor keaksaraan fungsional dalam pengelolaan pembelajaran pada program konseling dan supervisi tergolong cukup, yaitu dari 8 responden terdapat 5 atau sekitar $62.5 \%$ tutor yang memiliki kompetensi dalam kategori cukup. Namun demikian, masih terdapat indikator dalam penelitian ini yang memiliki prosentase yang relatif kecil diantaranya; kemampuan melaksanakan program konseling dan supervisi dan kemampuan memilih fasilitas pendukung program konseling dan supervisi.

Berdasarkan hasil analisis di atas, menunjukkan bahwa kompetensi tutor keaksaraan fungsional dalam pengelolaan pembelajaran pada sistem pembelajaran tuntas tergolong cukup, yaitu dari 8 responden terdapat 4 responden atau sekitar $50 \%$ tutor yang memiliki kompetensi dalam kategori cukup. Namun demikian, masih ada beberapa memiliki prosentase relatif kecil, diantaranya kemampuan menerapkan dan memahami strategi pembelajaran dengan pendekatan pedagogik, kemampuan mentransfer materi pembelajaran membaca, menulis, dan berhitung, dan keterampilan fungsional kepada peserta didik dan kemampuan memahami tingkat ketercapaian dan ketuntasan pembelajaran bagi peserta didik dari setiap item materi pembelajaran calistung dan keterampilan fungsional. Berdasarkan hasil analisis data di atas, menunjukkan bahwa kompetensi tutuor keaksaraan fungsional dalam pengelolaan pembelajaran pada sistem evaluasi pembelajaran tergolong cukup, yaitu dari 8 responden terdapat 4 responden atau sekitar $50 \%$ tutor memiliki kompetensi dalam kategori cukup. Namun demikian, berdasarkan hasil penelitian menunjukkan bahwa masih terdapat beberapa indikator yang memiliki nilai relatif kecil, diantaranya kemampuan memahami sistem evaluasi terhadap peserta didik yang meliputi tujuan penilaian, ruang lingkup, waktu, tata cara, analisis hasil, dan tindak lanjut penilaian. Dengan demikian prosentase kompetensi tutor keaksaraan fungsional dalam pembelajaran dari lima aspek yang dicobakan, yaitu (1) materi pembelajaran dan pemanfaatan bahan ajar; (2) memahami potensi peserta didik; (3) program konseling dan supervisi; (4) pembelajaran tuntas; dan (5) sistem evaluasi pembelajaran, dari 8 tutor keaksaraan fungsional yang diteliti tercermin 55,0 \% berkompetensi dan untuk lebih jelasnya dapat dilihat pada gambar berikut.

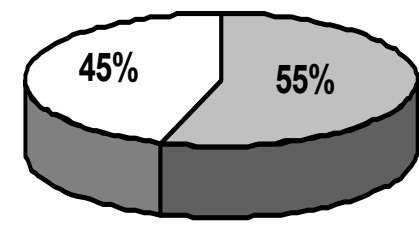

\begin{tabular}{|l|}
\hline Berkompetensi \\
$\square$ Belum Berkom petensi
\end{tabular}

Gambar 6. Kompetensi tutor keaksaraan fungsional

Percepatan pemberantasan buta aksara merupakan tanggung jawab bersama, terutama sebagai penilik PLS yang diberikan amanah untuk mengawasi, membimbing ,dan mengevaluasi proses pelaksanaan program keaksaraan fungsional. Pemerintah telah mengupayakan dan mencanangkan gerakan nasional percepatan pemberantasan buta aksara.

Dirjen Pendidikan Luar Sekolah telah menerbitkan berbagai buku yang berkaitan dengan penyusunan dan penggunaan bahan ajar keaksaraan fungsional, strategi dan metode pembelajaran, penyusunan rencana pembelajaran, teknik identifikasi kebutuhan belajar, penilaian pembelajaran, dan penilaian kemajuan dan hasil belajar pendidikan keaksaraan. Berdasarkan pemantauan, evaluasi, dan bimbingan penulis sebagai penilik PLS, penulis berkesimpulan bahwa kompetensi tutor berpengaruh signifikan terhadap percepatan pemberantasan buta aksara.

\section{KESIMPULAN DAN SARAN}

\section{Kesimpulan}

Berdasarkan hasil penelitian, dapat disimpulkan bahwa kompetensi tutor keaksaraan fungsional dalam pengelolaan pembelajaran di Kecamatan Wara Utara Kota Palopo Provinsi Sulawesi Selatan sebagai berikut. 
1. Kompetensi tutor keaksaraan fungsional dalam pengelolaan pembelajaran di Kecamatan Wara Utara Kota Palopo Provinsi Sulawesi Selatan pada aspek materi pembelajaran dan pemanfaatan bahan ajar secara umum masuk dalam kategori cukup, karena terdapat empat responden yang memperoleh nilai cukup, dan dari empat responden yang memperoleh nilai kurang terdapat dua responden yang memperoleh nilai 37 .

2. Kompetensi tutor keaksaraan fungsional dalam pengelolaan pembelajaran di Kecamatan Wara Utara Kota Palopo Provinsi Sulawesi Selatan pada aspek kemampuan memahami potensi peserta didik secara umum masuk dalam kategori kurang.

3. Kompetensi tutor keaksaraan fungsional dalam pengelolaan pembelajaran di Kecamatan Wara Utara Kota Palopo Provinsi Sulawesi Selatan pada aspek program konseling dan supervisi secara umum masuk dalam kategori cukup.

4. Kompetensi tutor keaksaraan fungsional dalam pengelolaan pembelajaran di Kecamatan Wara Utara Kota Palopo Provinsi Sulawesi Selatan pada aspek pembelajaran tuntas secara umum masuk dalam kategori cukup.

5. Kompetensi tutor keaksaraan fungsional dalam pengelolaan pembelajaran di Kecamatan Wara Utara Kota Palopo Provinsi Sulawesi Selatan pada aspek sistem evaluasi pembelajaran secara umum masuk dalam kategori cukup.

\section{Saran}

1. Kepada tutor dan pengelola PKBM se-Kota Palopo disarankan agar lebih memperdalam pemahamannya tentang konsep pengelolaan pembelajaran KF khususnya kemampuan memahami potensi peserta didik dan kepada ketua PKBM agar lebih proaktif memberikan dorongan dan bimbingan kepada tutor dalam mengimplementasikan konsep program keaksaraan fungsional yang telah diterbitkan oleh Dirjen Pendidikan Luar Sekolah.

2. Kepada semua pihak yang berkompeten disarankan agar proaktif mensosialisasikan dan melakukan bimbingan dan pelatihan kepada para tutor utamanya mengenai kompetensi tutor dalam pengelolaan pembelajaran keaksaraan fungsional secara komprehensif dan integral, kalau memungkinkan sebaiknya dilakukan uji kompetensi kepada para tutor secara berkala yang bertujuan meningkatkan kompetensi sebagai tenaga pendidik.

3. Diharapkan tutor memahami dengan baik modul keaksaraan fungsional sebagai arah, pedoman, dan panduan utama dalam mengelola proses belajar mengajar dan tutor diharapkan inovatif, berkreatifitas, dan proaktif merancang bahan pembelajaran tematik yang menyenangkan demi percepatan pemberantasan buta aksara.

4. Penilik PLS sebagai tenaga fungsional penjamin mutu, pelaksana teknis kegiatan pemantauan, penilaian, dan bimbingan penyelenggaraan Pendidikan Luar Sekolah mempunyai tugas pokok yaitu; merencanakan, melaksanakan, menilai, membimbing, dan melaporkan kegiatan penilikan Pendidikan Luar Sekolah, disarankan proaktif melakukan pembinaan kelompok belajar Keaksaraan fungsional agar tujuan program tersebut bisa diaktualisasikan dan manfaatnya berdampak secara cepat ke seluruh lapisan masyarakat yang masih buta aksara.

\section{DAFTAR PUSTAKA}

Acuan evaluasi pembelajaran program keaksaraan fungsional. (2005). Jakarta: Depdiknas, Ditjen Pendidikan Luar Sekolah dan Pemuda, Direktorat Pendidikan Masyarakat.

Acuan ketuntasan belajar (Pendidikan kesetaraan program Paket ABC). (2004). Jakarta: Depdiknas, Ditjen Pendidikan Luar Sekolah dan Pemuda, Direktorat Pendidikan Masyarakat.

Adnan, S. (2003). Pendidikan keaksaraan fungsional. Makassar: Dinas Pendidikan.

Bahan penilaian program keaksaraan fungsional. (2005). Jakarta: Depdiknas, Ditjen Pendidikan Luar Sekolah dan Pemuda, Direktorat Pendidikan Masyarakat.
Hasan, I. (1999). Pokok-pokok materi statistik 1 (Statistik deskriptif). Jakarta: Bumi Angkasa.

Himpunan keputusan tentang jabatan fungsional penilik. (2005). Jakarta:Depdiknas, Ditjen Pendidikan Luar Sekolah dan Pemuda, Direktorat Tenaga Teknis.

Jumair, R. (2005). Studi kompetensi guru dalam pelaksanaan kurikulum berbasis kompetensi pada SMK Negeri kota Makassar. Makassar: UNM.

Mardalis. (1995). Metode penelitian. Jakarta: Bumi Angkasa

Modul pengelolaan kelompok belajar KF. (2005). Jakarta: Depdiknas, Ditjen Pendidikan Luar Sekolah dan Pemuda, Direktorat Tenaga Teknis. 
Modul penyusunan dan penggunaan bahan ajar media pembelajaran KF. (2005). Jakarta: Depdiknas, Ditjen Pendidikan Luar Sekolah dan Pemuda, Direktorat Tenaga Teknis.

Modul penyusunan rencana pembelajaran KF. (2005). Jakarta: Depdiknas, Ditjen Pendidikan Luar Sekolah dan Pemuda, Direktorat Tenaga Teknis.

Modul strategi dan metode pembelajaran KF. (2005). Jakarta: Depdiknas, Ditjen Pendidikan Luar Sekolah dan Pemuda, Direktorat Tenaga Teknis.

Modul teknik identifikasi kebutuhan belajar KF. (2005). Jakarta: Depdiknas, Ditjen Pendidikan Luar Sekolah dan Pemuda, Direktorat Tenaga Teknis.

Pedoman diagnostik potensi peserta didik. (2004).Jakarta: Depdiknas.

Pedoman operasional penyelenggaraan program pendidikan masyarakat. (1998). Jakarta: Depdiknas, Ditjen Pendidikan Luar Sekolah dan Pemuda, Direktorat Tenaga Teknis.

Pedoman pelaksanaan pelayanan bimbingan dan konseling. (2004). Jakarta: Depdiknas.

Pedoman pembelajaran tuntas. (2004). Jakarta: Depdiknas.

Pedoman pemilihan dan pemanfaatan bahan ajar. (2004). Jakarta: Depdiknas.

Pedoman penilaian kemajuan dan hasil belajar pendidikan keaksaraan. (2005). Jakarta: Depdiknas, Ditjen Pendidikan Luar Sekolah dan Pemuda, Direktorat Pendidikan Masyarakat.

Pedoman supervisi pengajaran. (2004). Jakarta: Depdiknas.

Pedoman tutor kelompok belajar keaksaraan fungsional. (2003). Jakarta: Depdiknas, Ditjen Pendidikan Luar Sekolah dan Pemuda, Direktorat Pendidikan Masyarakat.

Pendampingan bagi tutor keaksaraan fungsional. (2005). Jakarta: Depdiknas, Ditjen Pendidikan
Luar Sekolah dan Pemuda, Direktorat Tenaga Teknis.

Pengelolaan pembelajaran keaksaraan fungsional. (2005). Jakarta: Depdiknas, Ditjen Pendidikan Luar Sekolah dan Pemuda, Direktorat Tenaga Teknis.

Pengembangan model pendidikan nonformal (Buku pintar bagi pamong belajar KF). (2005). Jakarta: Depdiknas, Ditjen Pendidikan Luar Sekolah dan Pemuda, Direktorat Tenaga Teknis.

Penilaian pembelajaran keaksaraan fungsional. (2005). Jakarta: Depdiknas, Ditjen Pendidikan Luar Sekolah dan Pemuda, Direktorat Tenaga Teknis.

Penyelengaraan program keaksaraan fungsional. (2005). Jakarta: Depdiknas, Ditjen Pendidikan Luar Sekolah dan Pemuda, Direktorat Tenaga Teknis.

Rusyan, T. (1989). Pendekatan dalam proses belajar mengajar. Bandung: Remadja Karya.

Sudjana. (1996). Metode statistik. Bandung: Tarsito.

Sugiyono, (2003). Statistika untuk penelitian. Bandung: Alfabeta.

Suharsimi, A. (1998). Prosedur penelitian (Suatu pendekatan praktek). Jakarta:Rineka Cipta.

Suharsimi, A. (2001). Dasar-dasar evaluasi pendidikan. Jakarta: Bumi Aksara.

Suprapto, CH. (1999). Kinerja pejabat eselon IV (Survei di Biro Kepegawaian Departemen Pendidikan dan Kebudayaan). Makalah.

Suryabrata, S. (2002). Metodologi penelitian. Jakarta: PT. Raja Grafindo Persada.

Syaiful. 2000. Guru dan anak didik dalam interaksi edukatif. Jakarta: Rineka Cipta.

Tim Redaksi. (2001). Kamus besar bahasa Indonesia.Ed. Ketiga. Jakarta: Balai Pustaka.

Undang-undang Republik Indonesia no. 20 tahun 2003 tentang sistem pendidikan nasional. (2003). Jakarta: Sekretariat Negara RI. 